\title{
Pain Management in the Acute Care Setting: Update and Debates
}

Author: Greta M Palmer ${ }^{1-3}$

\section{Affiliations}

${ }^{1}$ Department of Anaesthesia and Pain Management, Royal Children's Hospital Melbourne, Victoria, Australia;

${ }^{2}$ Murdoch Children's Research Institute, Melbourne, Victoria, Australia;

${ }^{3}$ Department of Paediatrics, Faculty of Medicine, Dentistry and Health Sciences, University of Melbourne, Melbourne, VIC, Australia;

Corresponding author: A/Prof Greta Palmer, Department of Anaesthesia and Pain Management, Royal Children's Hospital Melbourne, 50 Flemington Rd, Parkville Victoria 3052, Australia; Ph: +613 9345 5233, Fax:+613-9345 6003 e-mail: greta.palmer@rch.org.au

\section{Version 26 November 2015}

Conflict of interest statement: The author has no conflicts of interest to disclose.

Word count: 3009

Key words: pain, analgesia, children, emergency department, opioid, codeine, fentanyl intranasal

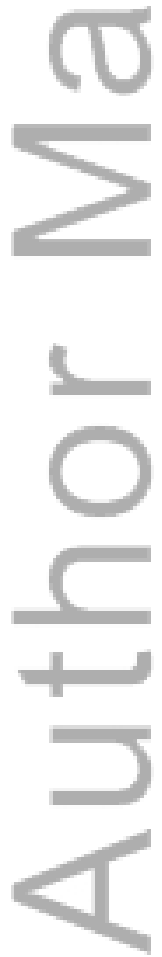

This is the author manuscript accepted for publication and has undergone full peer review but has not been through the copyediting, typesetting, pagination and proofreading process, which may lead to differences between this version and the Version of Record. Please cite this article as doi: $10.1111 /$ jpc.13134

This article is protected by copyright. All rights reserved. 


\section{Abstract (150) 142}

Pain management in the paediatric acute care setting is underutilised and can be improved. An awareness of the analgesic options available and their limitations is an important starting point. This article describes the evolving understanding of relevant pharmacogenomics and safety data of the various analgesic agents with a focus on agents available in Australia and New Zealand. It highlights the concerns with the use of codeine in children and discusses alternative oral opioids. Key features of oral, parenteral, inhaled and intranasal analgesic agents are discussed, as well as evidence supported use of sweet tasting solutions and non-pharmacological interventions. One of the biggest changes in acute care pain management has been the advent of intranasal fentanyl providing reliable potent analgesia without the need for intravenous access. The article will also address the issue of multimodal analgesia where a single agent is insufficient.

\section{3 key messages}

1. While alternative nonsteroidal anti-inflammatory analgesic agents and newer formulations have become available, oral and intravenous paracetamol and oral ibuprofen continue to be the mainstay of simple analgesic intervention in acutely ill and injured children. Recent research results have improved the understanding of the limitations of analgesic agents.

2. Codeine's efficacy is limited by an individual's ability to metabolise it to its active metabolite morphine. Concerns about a lack of efficacy in some children (due to the inability to metabolise codeine) and deaths in others (associated with ultrarapid metabolism), have led many paediatric institutions to remove or restrict codeine and replace it with other oral opioids.

3. As a recent key innovation, intranasal fentanyl provides potent rapid onset and safe analgesia in children without the need for intravenous access.

\section{Abbreviations:}

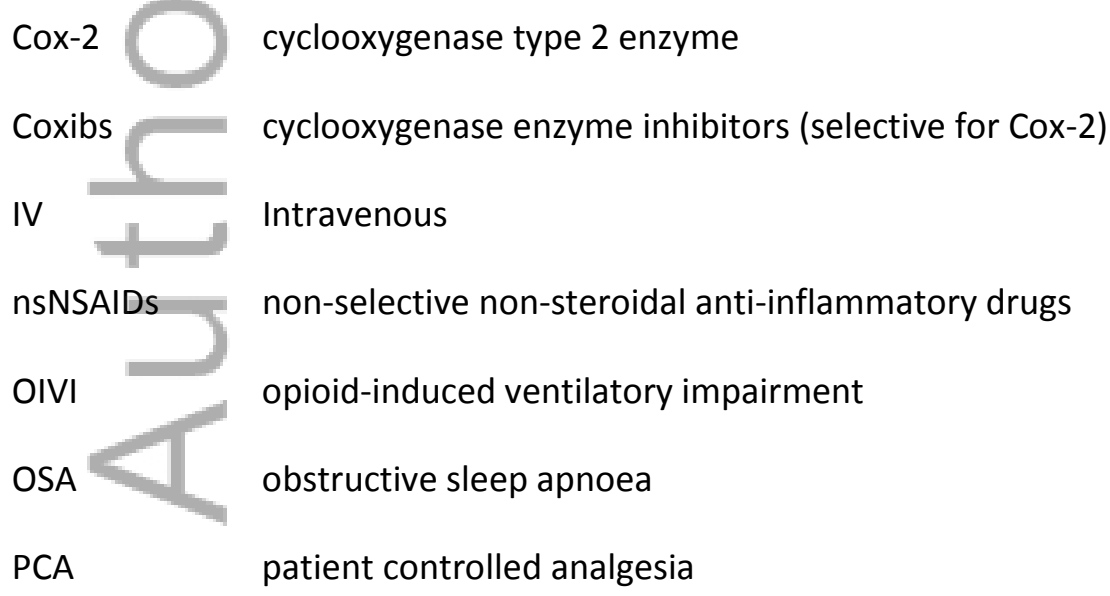




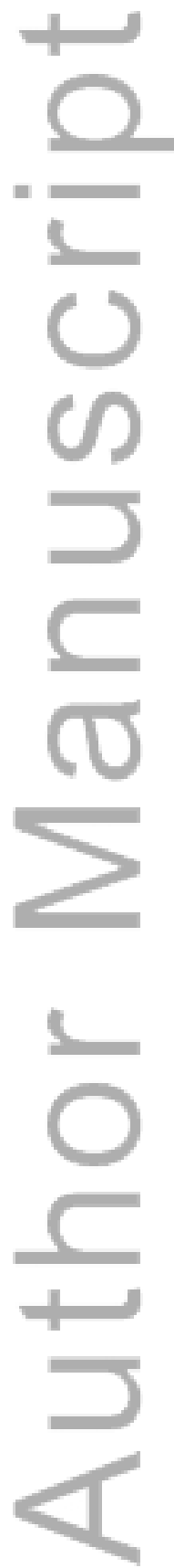

This article is protected by copyright. All rights reserved. 


\section{Introduction}

Upon attending an ED, children are subjected to diagnostic and therapeutic procedures which are associated with varying degrees of pain and distress ${ }^{1-5}$. They are commonly young and pre- or earlyverbal and disappointingly, analgesic intervention is used with low frequency ${ }^{3-5}$. This is in spite of the recognition that pain has long term consequences on a child's behaviour and reaction to future painful experiences ${ }^{2,6}$. The importance of minimising pain and distress in children is recognised in several clinical practice guidelines in the paediatric, emergency and pain literature ${ }^{6,7}$. Age and developmentally appropriate pain scoring tools should be used in children for assessment ${ }^{6}$ to then assist with determining the choice of analgesic intervention. This should then follow with reassessment to determine the response to analgesia.

This article provides an update to guide these choices for the analgesic management of children in the acute care setting. It presents information on the current debates around the adverse event profiles of the various analgesic agents used both commonly, and off-licence, and provides suggested escalation with multimodal intervention, when a single agent is ineffective. Simple analgesia: Paracetamol (acetaminophen)

Paracetamol is used for mild pain in children, and as an opioid-sparing agent for more severe pain ${ }^{6,8}$. The mechanism of action of paracetamol is debated ${ }^{9}$. Paracetamol is available in tablet, elixir, suppository and intravenous (IV) forms. All routes are efficacious and it is frequently a first-line analgesic intervention ${ }^{6,10}$. Peak plasma concentrations are achieved following oral administration reliably at 30 minutes and from then, closely approximate those following IV administration. With rectal administration, absorption is slow with delayed and erratic peaks in plasma concentrations, but the duration of effect is longer as compared with IV administration ${ }^{11}$. See Table 1 for suggested dosing. The IV route is used most commonly perioperatively and in intensive care, but is a consideration in emergency acute care when patients are vomiting and the avoidance of opioids is imperative.

Paracetamol use for pain and fever is generally safe in therapeutic doses ${ }^{6,12}$. Hepatotoxicity occurs with intentional overdose and is concerning with chronic dosing, prolonged fasting and severe illness. It is reported with both accidental supra-therapeutic and therapeutic dosing ${ }^{9,13}$. It is prudent to dose for lean body weight (as the impact of obesity/fatty liver infiltration is poorly elucidated) and to reduce dosing with long term administration or in liver impairment. There is active debate regarding whether paracetamol is protective or precipitates bronchospasm/asthma ${ }^{9}$. It has been used in patients with aspirin sensitive asthma (an old term now replaced by non-steroidal antiinflammatory drug exacerbated respiratory disease (NSAID-ERD).

\section{Simple analgesia: Non-selective non-steroidal anti-inflammatory drugs (nsNSAIDs) e.g. ibuprofen}

Cyclooxygenase (Cox) enzymes, Cox-1 and Cox-2, are responsible for the formation of prostanoids in the inflammatory pathway. Nonselective (ns)NSAIDs (eg ibuprofen, diclofenac, ketorolac and naproxen) variably inhibit these two enzymes to have combined anti-inflammatory and analgesic effects. Because Cox- 1 and Cox- 2 enzymes are present in multiple tissue sites, inhibitors have a range of other effects. NsNSAIDs are effective for mild to moderate pain and are equivalent or superior to paracetamol for paediatric postoperative pain management ${ }^{6,8,10}$. The commonly used nsNSAIDs equilibrate with the brain effect site more quickly than paracetamol ${ }^{6,10}$. NsNSAIDs are available in tablet/capsule, elixir, rectal and parenteral forms and are used first- and second-line or 
in combination as part of multimodal analgesic management. See Table 2 for suggested dosing of ibuprofen and diclofenac.

Like paracetamol, nsNSAIDs use for pain and fever is generally safe. Paediatric institutions vary in their 'acceptable lower age limit' for nsNSAID use. Some choose 12 months, while the labelling nominates a lower age (eg 3-6 months for ibuprofen) unsupported by safety data. The reason for reluctance is that nephrons are maturing until 2 years of age and single doses in neonates can reduce glomerular filtration rate by $20 \%$, albeit reversibly ${ }^{6,10}$. The risk benefit of nsNSAID use is therefore weighed against an infant's illness severity and comorbidities. The impact of multiple doses is uncertain. As in adults, nsNSAIDs are not to be co-administered with diuretics and angiotensin converting enzyme inhibitors. There is an important precaution in renal impairment, and hypovolaemic or compromised circulatory states, where acute kidney injury has occurred ${ }^{14,15}$. Gastric discomfort, gastritis and peptic ulceration are well-known adverse effects ${ }^{6,10}$ and patients receiving long-term dosing or at high risk acutely should be considered for co-treatment with acid suppression.

Anaphylaxis is extremely rare, but for allergic reactions, there is within class cross sensitivity. A concern is the variable impact of nsNSAIDs on asthma of different severity. In patients with mild asthma, nsNSAID use does not precipitate bronchospasm; with the anti-inflammatory effect possibly reducing outpatient attendances for asthma flares ${ }^{6,10}$. However, in a percentage of patients with moderate to severe asthma and coexistent nasal disease (indicated by allergic rhinosinusitis or polyps), NSAID-ERD can be precipitated, precluding their use ${ }^{6,10}$.

Debate continues about the adverse effects of nsNSAIDs on bone healing. Osteogenic activity is decreased by a Cox-2 mechanism, with studies varying in their conclusions as to whether fusion is impaired in orthopaedic surgery or long bone fractures in adults or children ${ }^{16,17}$. Short term use (3-14 days) of usual (not high) dose is considered acceptable.

The other issue is inhibition of platelets: reversible with nsNSAIDs but non-reversible with aspirin. This means nsNSAIDs should be avoided in low platelet states or conditions where bleeding is a risk. Postoperative bleeding rates are increased (by 2 to 20 fold: from $0-0.4 \%$ to $1.7-2.4 \%$ ) following single dose use in various adult surgery types ${ }^{18}$. The perioperative use of nsNSAIDs is avoided for surgery with high risk of postoperative bleeding. Use in tonsillectomy is controversial ${ }^{19}$. If a patient presents to the emergency department or general practice in pain where bleeding is of consequence (eg post tonsillectomy or with intracerebral pathology), the take home analgesic recommendation must be carefully considered (see below).

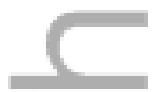

\section{Simple analgesia: Selective NSAIDs -Cyclooxygenase (cox)-2 inhibitors (or coxibs) eg celecoxib}

Coxibs are of theoretical consideration in acute care when nsNSAIDs are contraindicated and the clinician wants additional analgesia to paracetamol, while avoiding opioids and opioid induced ventilatory impairment (OIVI) or sedative effects (eg patients with obstructive sleep apnoea (OSA) or head injury). However, coxib use is off licence in Australia and New Zealand and paediatric trial data are limited ${ }^{6}$. Dosing information in children requires assessment and clarification and these agents are relatively expensive. Celecoxib is the oral coxib available most commonly in capsule form which 
can be dispersed, while some hospital pharmacies and compounding pharmacies are providing a suspension for paediatric dosing (that is not commercially available).

The main issue in acute care is that coxibs do not inhibit platelet activity. They may be prothrombotic in adult coronary and cerebrovascular disease but are an option for the child in pain post-tonsillectomy ${ }^{20}$ or post haemophiliac bleed ${ }^{21}$. As the renal effects of NSAIDs occur via a cox-2 mechanism ${ }^{15}$, it is essential that renal output is established before use. Epigastric discomfort occurs (similar to placebo rates) but peptic ulceration rates are low. The other indication for coxibs is in NSAID-ERD and allergy to nsNSAIDs where coxib use appears safe ${ }^{6}$. The safety profile in paediatric overdose of celecoxib is very good ${ }^{22}$.

\section{Opioids}

The term opiate refers to substances derived from the opium poppy, and a narcotic is an agent that induces sleep. The term opioid refers to agents that bind opioid receptors with effect. Therefore it is best to replace the terms "opiate" and "narcotic" with the class label of "opioid", although the past literature uses these terms interchangeably. Opioids are effective analgesics but use is associated with many negative effects including itch, nausea and vomiting (30-40\% of patients), constipation ( $90 \%$ of patients) and dose dependent sedation and OIVI.

\section{Opioids: Codeine}

Codeine has been used for decades in children, popular due to over the counter availability including as a combination preparation. For analgesic efficacy, codeine requires conversion to its active metabolite, morphine, by cytochrome P450 (CYP)2D6. Pharmacogenomic investigation reveals 100 genes for this liver enzyme and 4 phenotypes of enzyme activity: poor (PM), intermediate (IM), extensive ( $\left(E M={ }^{\prime}\right.$ normal') and ultra-rapid metabolisers $(U M)^{6}$. The PM/IM phenotype is an explanation for codeine's poor efficacy in some comparative analgesic trials and being falsely attributed as causing less sedation and respiratory depression than morphine. People with the UM phenotype produce high morphine concentrations with parallel increase in side effects. The issue to highlight is recent deaths reported in association with UM and EM phenotype in breastfed neonates whose mothers took codeine ${ }^{23}$, and toddlers ${ }^{24}$ and older obese children ${ }^{25}$, where codeine was used for pain or cough. Consequently, several regulatory bodies have relabelled codeine's product information ${ }^{26}$, the World Health Organisation has removed codeine from its analgesic ladder ${ }^{27}$ and tertiary paediatric centres are removing it from formulary.

The phenotypic representation varies with different racial origin. Asians mostly have normal phenotype (EM 92\%). Approximately $10 \%$ of Caucasians and Europeans metabolise poorly or not at all, while $10 \%$ are at risk as UMs. Patients of African and Arabic origin are at greatest risk with 26$30 \%$ UMs, while $20 \%$ are PMs with no analgesic benefit. Thus, in acute care it is best to avoid codeine and use an alternative opioid. If no alternative is available, then codeine is best administered under medical supervision and not for the first time as a night time rescue post discharge. 


\section{Opioids: Morphine immediate release and sustained release (MSContin ${ }^{\circledR}$ )}

Morphine is the gold standard opioid ${ }^{6}$. Oral tablet or elixir is available in various concentrations, but these are unflavoured and bitter reducing the acceptability by children (see oxycodone below). Extended duration 'sustained' release MSContin ${ }^{\circledR}$ is available in various tablet sizes and also granules ( 20 and $30 \mathrm{mg}$ sachets). The latter is useful when tablets are refused or administration by enteral tube is required. Large scale audit supports the safety of IV morphine via nurse controlled bolus with continuous infusion ${ }^{28}$, patient controlled analgesic (PCA) device or by nurse or parental proxy ${ }^{29}$.

\section{Opioids: Oxycodone immediate and controlled release (OxyContin ${ }^{\circledR}$, Targin $\left.^{\circledR}\right)$}

Oxycodone orally has recently become available in IV form, but oral administration has established efficacy in various paediatric settings ${ }^{6}$. It is available as tablet (immediate and extended 'controlled' release) and elixir (butterscotch flavour; $1 \mathrm{mg} / \mathrm{mL}, 200 \mathrm{~mL}$ bottle). The elixir's palatability has increased the use of this agent in children. For safe discharge prescription, pharmacies can dispense limited volumes (eg a few prefilled syringes or small $20 \mathrm{~mL}$ containers).

The continuous release $O x y C o n t i{ }^{\circledR}$ has active drug in its outer core, with improved pharmacokinetic profile over MSContin ${ }^{\circledR}$. Unfortunately, OxyContin ${ }^{\circledR}$ is replacing heroin as a drug of abuse. The inner drug core is accessed for subsequent injection (drug misuse website: www.bluelight.com). Drug manufacturers have consequently developed a tamper resistant matrix (OxyContin $\left.{ }^{\circledR}-\mathrm{OP}\right)$ and a naloxone extended release combination $\operatorname{Targin}^{\circledR}$. The latter offers therapeutic advantage as the incorporated naloxone binds intestinal opioid receptors reducing constipation incidence without reduced analgesic efficacy (as absorbed naloxone experiences 100\% first pass liver metabolism).

\section{Opioids: Fentanyl}

Fentanyl is potent and more lipid soluble than morphine and used in children via IV, intranasal (IN), epidural (postoperative), trans-buccal and transdermal routes (the latter in opioid tolerant cancer patients) $)^{6}$. After IV administration, fentanyl affords rapid onset and short duration of effect.

Intranasal administration (via syringe or metered aerosolised device: MAD; See Figure 1) is increasingly used including in children ${ }^{30,31}$, providing effective analgesia for moderate to severe pain (eg in trauma, fracture, burns) similar to IV and oral morphine. The IN route offers convenience when no IV access is available, with similar onset time to IV (2-5 minutes) and longer duration ${ }^{32}$. High concentration $\left(100-300 \mathrm{mcg} / \mathrm{mL}\right.$ ) low volume administration was initially studied ${ }^{33}$. 'Usual' concentration (standard IV vial: $50 \mathrm{mcg} / \mathrm{mL}$ ) is also efficacious ${ }^{34}$ and is readily available and used in Australian and New Zealand EDs ${ }^{35}$ (reducing confusion with stocking multiple concentrations). See Table 2 for IV and IN dosing and Table 3 for indications. A practical tip is to direct the MAD 45 degrees upwards to spray the turbinates, rather than horizontally along the nasal floor (where drug runs to the pharynx and is swallowed, reducing bioavailability and efficacy).

\section{Other analgesic agents \\ Tramadol}

This article is protected by copyright. All rights reserved. 
Tramadol is used off licence in the paediatric perioperative setting ${ }^{6}$, via various routes. It is effective for somatic and also neuropathic pain: by noradrenaline and serotonin reuptake inhibition $(70 \%$ of effect) and mu-opioid effect (30\%) via its active metabolite (O-desmethy-tramadol; formed by CYP2D6). See Table 2 for dosing. Adverse effects of nausea and vomiting, dizziness and sedation are similar to opioids, with reduced itch, constipation and respiratory impairment. Naloxone administration will reverse adverse effects only in part. In the acute care setting, tramadol should be used in place of opioids for moderate to severe pain when opioids are contraindicated (eg OSA) or causing side effects, or when opioid resistant pain is present (see below). A precaution is that tramadol precipitates seizures in epileptics or seizure prone patients (usually at high doses). A practical tip for IV administration is to infuse it slowly IV over 15 to 20 minutes to avoid a nausea bolus effect. Tramadol in oral immediate release form is most commonly a capsule the contents of which can be dispersed in water for divided administration to smaller children. A concentrated formulation is available for use in adult palliative care as $100 \mathrm{mg}$ per $\mathrm{mL}$. This should not be used in children as there is risk of dosing confusion and overdose ${ }^{6}$. New Zealand has recently launched a commercial $10 \mathrm{mg}$ per $\mathrm{mL}$ suspension. Tramadol sustained release tablets are not used in the acute setting, but may be used postoperatively in the older child.

\section{Tapentadol (Palexia SR ${ }^{\circledR}$ )}

Tapentadol is effective via noradrenaline reuptake inhibition (90\%) and opioid effect (10\%). It is currently licensed for use in chronic pain and may have reduced abuse potential. It is mentioned here as, once the immediate release form is available, it may be used for patients in acute pain susceptible to opioid induced nausea, vomiting, constipation and OIVI.

\section{Ketamine}

In addition to its traditional use for dissociative sedation, ketamine can be used as an analgesic in the $\mathrm{ED}^{35,36}$ and perioperatively, via oral, intranasal and IV routes ${ }^{6}$. Intramuscular route is less preferable to the other routes, but is a reliable alternative when IV access is challenging for acute pain management and procedural sedation in the ED, for example in chubby infants. Intranasal route has been used for analgesia in the prehospital setting with a wide range in dose ${ }^{6}$. Analgesic IV doses 0.1-0.5 mg per kg are sub-anaesthetic (i.e. the patient is coherent and not dissociated). It is particularly useful adjunct in opioid resistant pain.

\section{Inhaled methoxyflurane}

Methoxyflurane is a popular Australian prehospital analgesic intervention in patients with various pains, most commonly resulting from trauma. It is used in children and is $78 \%$ effective ${ }^{37}$, more so for extremity pain rather than the subsequent fracture manipulation ${ }^{38}$.

\section{Sweet tasting solutions (eg sucrose) and physical interventions for infants}

Sweet tasting solutions (sucrose, glucose, fructose, supplemental breast milk etc) effectively reduce pain and/or behavioural response to skin breaking procedures (heel-lance, venipuncture, IV and arterial cannulation) in preterm and term neonates ${ }^{39,40}$ and older infants ( 1 to 12 months, including when having immunisation ${ }^{41}$ ), but not once toddler- or school-aged ${ }^{42}$. The optimum 
concentration/dose is still unclear but this safe simple intervention should be routinely offered to infants in the acute care setting. Physical interventions that reduce pain scores or behaviours include non-nutritive sucking ${ }^{39}$, facilitated tucking ${ }^{43}$, and parental holding ${ }^{44}$. When these physical interventions are added to sucrose or breastfeeding, the combinations are superior.

\section{Non-pharmacological interventions -physical and psychological for older children}

Use of cold (Coolsense ${ }^{\circledR}$ or ice or vapocoolant) or vibration and cold (Buzzy ${ }^{\circledR}$ ) achieve analgesia in children prior to venipuncture/cannulation ${ }^{6}$. Upright position is associated with reduced crying time over supine ${ }^{44}$.

Distraction (all ages: music, play, books, video, breathing, guided imagery and virtual reality) and hypnosis are efficacious for procedural analgesia ${ }^{45-47}$. Distraction requires no child preparation and can be directed by the parent or trained assistant and should be routinely performed for all paediatric emergency department and office procedures.

\section{Multimodal analgesia and interventions for 'opioid resistant' pain}

Multimodal analgesia is a term describing the administration of 3 or more analgesic agents. This typically includes paracetamol, an nsNSAID or coxib, an opioid and/or tramadol. For mild pain, administration is via the oral route, usually prn schedule, in a stepwise manner with a lower dose of opioid or tramadol administered of the prescribed range. For moderate to severe pain, simple analgesics are prescribed 'strictly' (ie regularly) with prn dosing of a full dose of opioids or tramadol. Oral route can be used or parenteral administration if more rapid onset is required or vomiting or ileus/bowel obstruction is present. There is a probable optimal dose and timing interaction between paracetamol and nsNSAID ${ }^{10}$ and tramadol, with more study required to inform administration practices and whether these medications should be given simultaneously or alternated with a delay.

For severe pain, uncontrolled by oral opioid or intermittent IV tramadol, then the next step is to add parenteral analgesia with opioid infusion (e.g. morphine 10-30mcg per kg per h) with nurse initiated boluses (morphine 10-20mcg per $\mathrm{kg}$ ) or bolus only via PCA device. If pain is still inadequately controlled, the options are to increase the background opioid infusion, or change the opioid.

'Opioid resistant' pain is commonly of neuropathic origin or following extensive burns or multitrauma. There is evidence that aggressive early treatment can reduce the development of chronic pain and the incidence of post-traumatic stress disorder symptoms and syndrome ${ }^{6}$. When a patient's pain remains uncontrolled despite multimodal intervention and high-end opioid dosing, specialised treatments including ion channel blockers such as: oral gabapentin 5-10 mg per kg, IV lignocaine 1-2 mg per kg, ketamine (IV, IN or subcutaneous: SC) titrated in 0.1-0.2 mg per kg boluses and then IV/SC infusion of 0.1 to $0.2 \mathrm{mg}$ per kg per h. Further options are clonidine (for anxiolysis and opioid sparing effect), benzodiazepines (for anxiolysis and pain from muscle spasm eg diazepam) and local anaesthetic regional block or infusion. Specialist consultation is advisable.

\section{Conclusion}

This article is protected by copyright. All rights reserved. 
Pharmacological and non-pharmacological interventions are available and achieve effective analgesia for children with pain from various sources and of varying severity. To manage acute pain appropriately and avoid long term consequences of inadequately managed pain, increased use of analgesic agents and techniques is to be encouraged within the confines of known adverse event profiles.

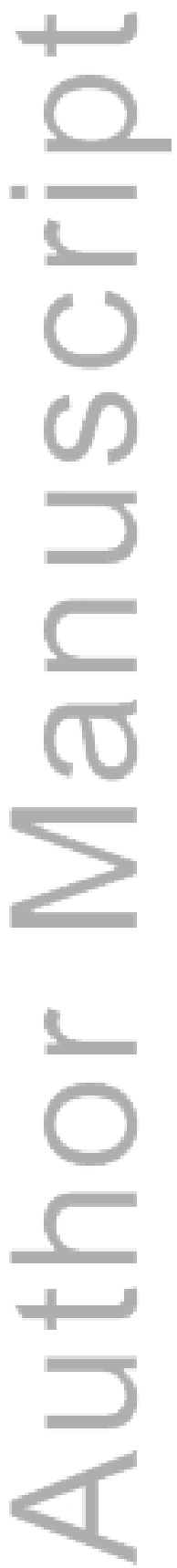

This article is protected by copyright. All rights reserved. 
Table 1: Suggested paracetamol dosing according to route and child's age based on lean body weight

\begin{tabular}{|c|c|c|c|c|}
\hline $\begin{array}{l}\text { Paracetamol } \\
\text { Route and age } \\
\text { of child }\end{array}$ & Loading dose & $\begin{array}{l}\text { Continued } \\
\text { dosing }\end{array}$ & $\begin{array}{l}\text { Maximum } \\
\text { acute dosing }\end{array}$ & Chronic dosing \\
\hline $\begin{array}{l}\text { Paracetamol PO } \\
\text { in older children } \\
\text { (Panadol }^{\mathrm{TM}} \text {, } \\
\text { Tylenol' }^{\mathrm{TM}} \text {, } \\
\left.\text { Dymadon }^{\mathrm{TM}}\right)\end{array}$ & $\begin{array}{l}\text { Loading dose } \\
\text { routine in some } \\
\text { centres; may } \\
\text { depend upon } \\
\text { whether } \\
\text { continued dosing } \\
\text { is planned } \\
\text { consider } 20- \\
30 \mathrm{mg} / \mathrm{kg} \\
\text { (maximum 1000- } \\
1500 \mathrm{mg} \text { ) }\end{array}$ & $\begin{array}{l}15 \mathrm{mg} / \mathrm{kg} \\
\text { (maximum } \\
1000 \mathrm{mg} \text { ) } \\
4 \text { to } 6 \\
\text { hourly }\end{array}$ & $\begin{array}{l}90 \mathrm{mg} / \mathrm{kg} / \text { day } \\
\text { for } 2-3 \text { days in } \\
\text { children } \\
\text { then } \\
60 \mathrm{mg} / \mathrm{kg} / \text { day } \\
\text { (maximum } \\
4000 \mathrm{mg} / \text { day) }\end{array}$ & $\begin{array}{l}45 \mathrm{mg} / \mathrm{kg} / \mathrm{day} \\
\text { (maximum } 3000 \mathrm{mg} / \text { day) }\end{array}$ \\
\hline $\begin{array}{l}\text { Paracetamol PR } \\
\text { in infants and } \\
\text { older children }\end{array}$ & $\begin{array}{l}\text { 40mg/kg } \\
\text { (maximum } 1000 \\
\mathrm{mg} \text { ) }\end{array}$ & $\begin{array}{l}20 \mathrm{mg} / \mathrm{kg} \\
\text { (maximum } \\
1000 \mathrm{mg} \text { ) } \\
6 \text { hourly }\end{array}$ & $\begin{array}{l}80 \mathrm{mg} / \mathrm{kg} / \mathrm{day} \\
\text { Safety of } \\
\text { multiday } \\
\text { duration } \\
\text { unknown }\end{array}$ & Data lacking \\
\hline $\begin{array}{l}\text { Paracetamol } \\
\text { PO/IV in infants } \\
\text { and IV in older } \\
\text { children }\end{array}$ & $\begin{array}{l}15 \mathrm{mg} / \mathrm{kg} \\
\text { (maximum } 1000 \\
\mathrm{mg} \text { ) }\end{array}$ & $\begin{array}{l}15 \mathrm{mg} / \mathrm{kg} \\
\text { (maximum } \\
1000 \mathrm{mg} \text { ) } \\
\text { 6hourly }\end{array}$ & $\begin{array}{l}60 \mathrm{mg} / \mathrm{kg} / \mathrm{day} \\
\text { (maximum } \\
1000 \mathrm{mg} 6 \\
\text { hourly) }\end{array}$ & $\begin{array}{l}45 \mathrm{mg} / \mathrm{kg} / \mathrm{day} \\
\text { (maximum } 750 \mathrm{mg} 6 \\
\text { hourly or } 1000 \mathrm{mg} 8 \\
\text { hourly) }\end{array}$ \\
\hline $\begin{array}{l}\text { Paracetamol PO } \\
\text { and IV } \\
\text { Neonates }\end{array}$ & $10 \mathrm{mg} / \mathrm{kg}$ & $\begin{array}{l}10 \mathrm{mg} / \mathrm{kg} 6 \\
\text { hourly }\end{array}$ & $\begin{array}{l}40- \\
45 \mathrm{mg} / \mathrm{kg} / \text { day }\end{array}$ & $\begin{array}{l}\text { Adjust according to liver } \\
\text { function including } \\
\text { unconjugated } \\
\text { hyperbilirubinaemia }\end{array}$ \\
\hline $\begin{array}{l}\text { Paracetamol IV } \\
\text { Premature }\end{array}$ & $10 \mathrm{mg} / \mathrm{kg}$ & $\begin{array}{l}10 \mathrm{mg} / \mathrm{kg} 12 \\
\text { hourly }\end{array}$ & $20 \mathrm{mg} / \mathrm{kg} /$ day & $\begin{array}{l}\text { Above comment applies } \\
\text { Limited data to inform } \\
\text { acute or chronic dosing in } \\
\text { this age group and nil for } \\
\text { oral dosing }\end{array}$ \\
\hline
\end{tabular}

IV intravenous PO per os =oral route PR per rectum=rectal route

This article is protected by copyright. All rights reserved. 
Table 2 Suggested sucrose, NSAID (nsNSAID and Coxib) and opioid dosing in children

\begin{tabular}{|c|c|c|c|}
\hline Analgesic & $\begin{array}{l}\text { Loading or dose } \\
\text { titration }\end{array}$ & $\begin{array}{l}\text { Continued } \\
\text { dosing }\end{array}$ & Maximum acute dosing \\
\hline Sucrose/Glucose & $\begin{array}{l}\text { Optimal dose and } \\
\text { concentration } \\
\text { unknown }\end{array}$ & $\begin{array}{l}20-50 \% \\
0.5 \mathrm{~mL}-2 \mathrm{~mL} \\
4 \text { times per } \\
\text { day }\end{array}$ & $\begin{array}{l}\text { Lower doses eg } 0.2 \mathrm{~mL} \text { are suggested in } \\
\text { premature. Consider capping at } 3 \text { to } 4 \\
\text { doses per day; but the safety of } \\
\text { repeated dosing is unknown }\end{array}$ \\
\hline \multicolumn{4}{|l|}{ nsNSAIDs: } \\
\hline $\begin{array}{l}\text { Ibuprofen PO } \\
\text { (Nurofen }^{\mathrm{TM}}, \text { Brufen }^{\mathrm{TM}} \text { ) }\end{array}$ & $10 \mathrm{mg} / \mathrm{kg}$ & $\begin{array}{l}5-10 \mathrm{mg} / \mathrm{kg} 6 \\
\text { or } 8 \text { hourly } \\
\text { With meals }\end{array}$ & $\begin{array}{l}600-800 \mathrm{mg} \text { 6hourly } \\
\text { (note NNTs decrease with increasing } \\
\text { dose; note higher than the product } \\
\text { information maximum) }\end{array}$ \\
\hline $\begin{array}{l}\text { Diclofenac PO/PR } \\
\left(\text { Voltaren }^{\mathrm{TM}}, \text { Fenac }^{\mathrm{TM}}\right)\end{array}$ & $2 \mathrm{mg} / \mathrm{kg}$ & $\begin{array}{l}1-2 \mathrm{mg} / \mathrm{kg} 6 \\
\text { to } 8 \text { hourly }\end{array}$ & $\begin{array}{l}50-75 \mathrm{mg} 8 \text { hourly } \\
\text { (note NNT data not assessed; this is } \\
\text { the only nsNSAID which has a } \\
\text { proposed ceiling effect) }\end{array}$ \\
\hline \multicolumn{4}{|l|}{$\begin{array}{l}\text { Coxib or Cox-2 } \\
\text { inhibitor: }\end{array}$} \\
\hline $\begin{array}{l}\text { Celecoxib PO } \\
\left(\text { Celebrex }^{\mathrm{TM}}, \text { Celexi }^{\mathrm{TM}}\right)\end{array}$ & $4-6 \mathrm{mg} / \mathrm{kg}$ & $\begin{array}{l}2-4 \mathrm{mg} / \mathrm{kg} 12 \\
\text { hourly }\end{array}$ & $200-400$ mg 12 hourly \\
\hline \multicolumn{4}{|l|}{ Opioid } \\
\hline Codeine PO & & $\begin{array}{l}0.5-1 \mathrm{mg} / \mathrm{kg} \\
4 \text { hourly }\end{array}$ & 30-60 mg 6 hourly \\
\hline $\begin{array}{l}\text { Oxycodon } \\
\text { (Oxynorm } \\
\text { Endone }^{T M} \text { ) }\end{array}$ & & $\begin{array}{l}0.1-0.2 \mathrm{mg} / \mathrm{kg} \\
\text { PO } 4 \text { hourly }\end{array}$ & $\begin{array}{l}\text { Note more potent than oral morphine } \\
\text { in } 2: 3 \text { ratio } \\
\text { Usual maximum 5-10mg } 4 \text { hourly; } \\
\text { higher and or more frequent doses } \\
\text { may be used following step down from } \\
\text { PCA and in cancer pain }\end{array}$ \\
\hline Oxycodone IV & $\begin{array}{l}10-50 \mathrm{mcg} / \mathrm{kg} \mathrm{IV} \\
\text { Titration to a } \\
\text { maximum of } 10 \mathrm{mg}\end{array}$ & $\begin{array}{l}\text { Depends on } \\
\text { indication }\end{array}$ & Equipotent to IV morphine \\
\hline Morphine PO & & $\begin{array}{l}0.25- \\
0.5 \mathrm{mg} / \mathrm{kg} \\
4 \text { hourly }\end{array}$ & $\begin{array}{l}\text { Usual maximum } 7.5-15 \mathrm{mg} 4 \text { hourly; } \\
\text { higher and or more frequent doses } \\
\text { may be used following step down from } \\
\text { PCA and in cancer pain }\end{array}$ \\
\hline Morphine IV & $\begin{array}{l}10-50 \mathrm{mcg} / \mathrm{kg} \\
\text { (titration to } \\
\text { maximum of } 5- \\
10 \mathrm{mg} \text { ) }\end{array}$ & $\begin{array}{l}\text { Depends on } \\
\text { indication }\end{array}$ & $\begin{array}{l}0.1 \mathrm{mg} / \mathrm{kg} \text { or } 10 \mathrm{mg} \text { usual maximum; in } \\
\text { severe pain higher end dosing may } \\
\text { have been used - then consider opioid } \\
\text { sparing agents or agents for opioid } \\
\text { resistant pain }\end{array}$ \\
\hline Fentanyl IN & Load $1.5 \mathrm{mcg} / \mathrm{kg}$ & $\begin{array}{l}0.5-1.5 \\
\mathrm{mcg} / \mathrm{kg} \\
10 \text { minutely }\end{array}$ & $3 \mathrm{mcg} / \mathrm{kg}$ \\
\hline Fentanyl IV & & $0.02-$ & $2 \mathrm{mcg} / \mathrm{kg}$ usual maximum $100 \mathrm{mcg}$ \\
\hline
\end{tabular}

This article is protected by copyright. All rights reserved. 


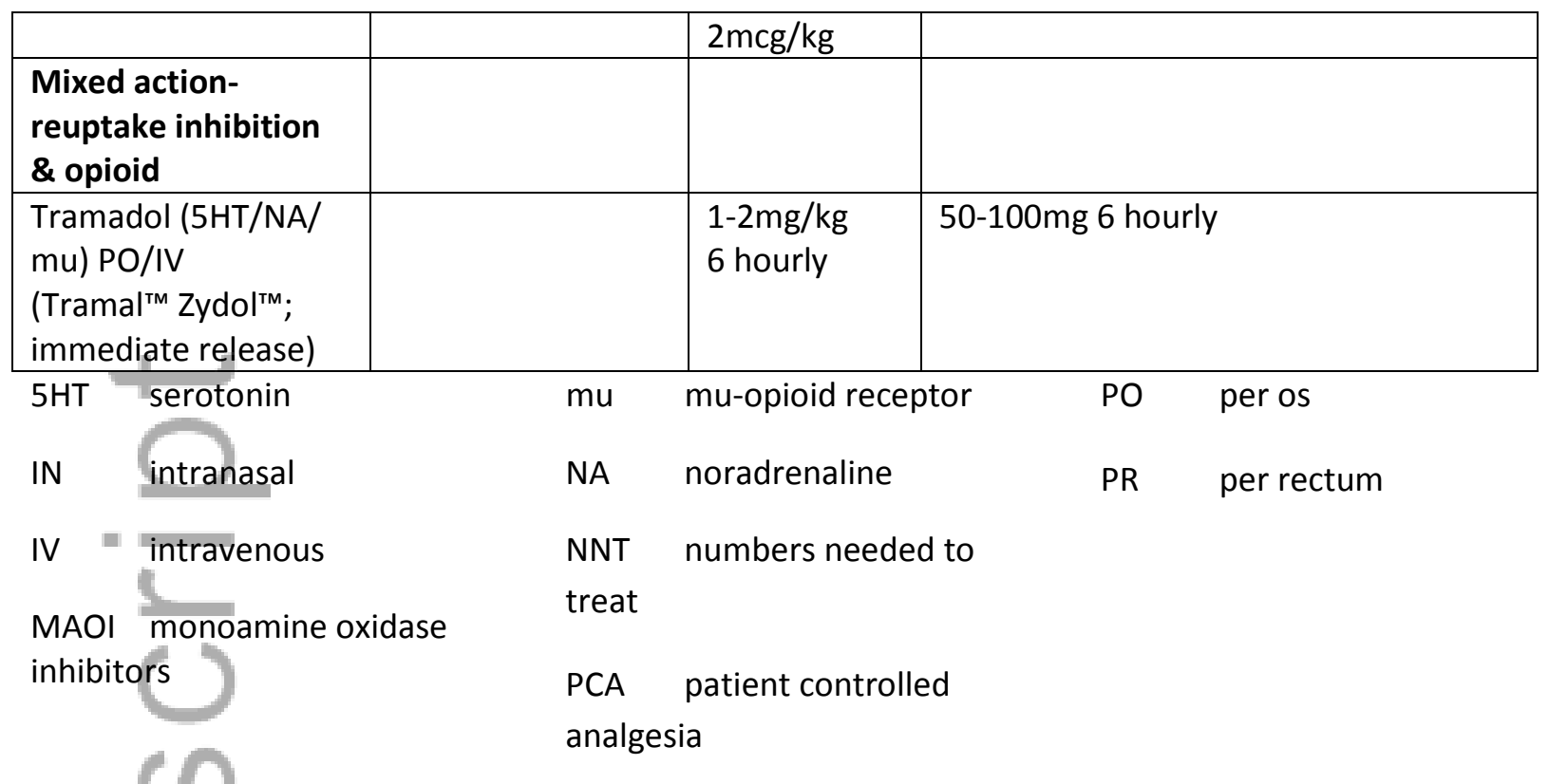

This article is protected by copyright. All rights reserved. 
Table 3: Analgesic agents, their adverse events, precautions and contraindications and practical tips

\begin{tabular}{|c|c|c|c|c|}
\hline Analgesic & Adverse events & Precautions & Contraindications & Practical tip \\
\hline Paracetamol & Hepatotoxicity & $\begin{array}{l}\text { Obesity, liver } \\
\text { disease, severe } \\
\text { illness, } \\
\text { prolonged fasting }\end{array}$ & Hepatic failure & $\begin{array}{l}\text { Watch for ALT rise } \\
\text { ( }>3 \text { times baseline) } \\
\text { and or ALT:AST } \\
\text { ratio of }>3\end{array}$ \\
\hline $\begin{array}{l}\text { nsNSAIDs: } \\
\text { eg Ibuprofen } \\
\text { Diclofenac }\end{array}$ & $\begin{array}{l}\text { Nausea, peptic } \\
\text { irritation/ulceration, } \\
\text { glomerular filtration } \\
\text { decrease, } \\
\text { impaired platelet } \\
\text { function }\end{array}$ & $\begin{array}{l}\text { Renal impairment, } \\
\text { surgery with } \\
\text { bleeding risk, } \\
\text { NSAID-ERD }\end{array}$ & $\begin{array}{l}\text { Active bleeding; } \\
\text { untreated peptic } \\
\text { ulcer disease }\end{array}$ & $\begin{array}{l}\text { Withhold if } \\
\text { circulatory status } \\
\text { compromised }\end{array}$ \\
\hline $\begin{array}{l}\text { Cox-2 } \\
\text { inhibitor: } \\
\text { Celecoxib }\end{array}$ & $\begin{array}{l}\text { Some epigastric } \\
\text { intolerance }\end{array}$ & Renal impairment & & $\begin{array}{l}\text { Withhold if } \\
\text { circulatory status } \\
\text { compromised } \\
\text { Safe in NSAID-ERD } \\
\text { and NsNSAID } \\
\text { allergy }\end{array}$ \\
\hline \multicolumn{5}{|c|}{ Opioids: } \\
\hline Codeine PO & $\begin{array}{l}\text { Shared with rest of } \\
\text { opioid class below; } \\
\text { Phenotypic variation } \\
\text { with conversion to } \\
\text { active metabolite } \\
\text { (morphine) resulting in } \\
\text { either analgesic failure } \\
\text { or excess adverse } \\
\text { events }\end{array}$ & $\begin{array}{l}\text { Patients with } \\
\text { OSA/OIVI or having } \\
\text { adeno-tonsillectomy } \\
\text { Particularly if racial } \\
\text { origin has high } \\
\text { PM/UM rates }\end{array}$ & $\begin{array}{l}\text { [Some countries have } \\
\text { altered product } \\
\text { labelling to exclude } \\
\text { use under } 16-18 \\
\text { years and or for } \\
\text { paediatric adeno- } \\
\text { tonsillectomy] }\end{array}$ & $\begin{array}{l}\text { Use alternative } \\
\text { opioid where } \\
\text { available; trial } \\
\text { administration } \\
\text { under medical } \\
\text { supervision in } \\
\text { daylight hours }\end{array}$ \\
\hline $\begin{array}{l}\text { Oxycodone } \\
\text { PO/IV } \\
\text { Morphine PO } \\
\text { Morphine IV } \\
\text { Fentanyl IN } \\
\text { Fentanyl IV }\end{array}$ & $\begin{array}{l}\text { Nausea, vomiting } \\
\text { Constipation } \\
\text { Sedation } \\
\text { OIVI } \\
\text { Itch }\end{array}$ & $\begin{array}{l}\text { OSA/OIVI } \\
\text { Head injury } \\
\text { Neurosurgery } \\
\text { (avoid or use opioid } \\
\text { sparing agents } \\
\text { preferentially; } \\
\text { consider lower } \\
\text { doses and observe } \\
\text { effects) }\end{array}$ & & $\begin{array}{l}\text { Give incremental } \\
\text { doses and observe } \\
\text { effect (titrate to } \\
\text { effect); co-treat } \\
\text { nausea and } \\
\text { vomiting and } \\
\text { constipation } \\
\text { Intranasal } \\
\text { administration: } \\
\text { angle MAD up or } \\
\text { tilt head back if } \\
\text { using syringe to } \\
\text { coat turbinates } \\
\text { and not nasal floor }\end{array}$ \\
\hline $\begin{array}{l}\text { Mixed action: } \\
\text { Tramadol } \\
\text { (5HT/NA/ } \\
\mathrm{mu} \text { ) }\end{array}$ & $\begin{array}{l}\text { Similar rates of nausea, } \\
\text { vomiting and sedation } \\
\text { to opioids } \\
\text { Less constipation, OIVI } \\
\text { and itch }\end{array}$ & $\begin{array}{l}\text { Seizure disorder or } \\
\text { predisposition. } \\
\text { Modify doses or } \\
\text { avoid } \\
\text { coadministration } \\
\text { with other } 5 \mathrm{HT} \\
\text { reuptake inhibiting }\end{array}$ & & $\begin{array}{l}\text { Give slowly as IV } \\
\text { bolus (eg over 15- } \\
20 \text { minutes) }\end{array}$ \\
\hline
\end{tabular}




\begin{tabular}{|c|c|c|c|}
\hline & & $\begin{array}{l}\text { agents such as } \\
\text { TCADs, SSRIs, } \\
\text { MAOls }\end{array}$ & \\
\hline $5 \mathrm{HT}$ & serotonin & noradrenaline & oral \\
\hline IN & intranasal & $\begin{array}{l}\text { OSA obstructive sleep } \\
\text { apnoea }\end{array}$ & $\begin{array}{l}\text { SSRI selective serotonin } \\
\text { reuptake inhibitor }\end{array}$ \\
\hline $\begin{array}{l}\text { MAC } \\
\text { inhit }\end{array}$ & monoamine oxidase & $\begin{array}{l}\text { OIVI opioid induced } \\
\text { ventilatory impairment }\end{array}$ & $\begin{array}{l}\text { TCAD tricyclic } \\
\text { antidepressant }\end{array}$ \\
\hline
\end{tabular}

$\mathrm{mu}=$ mu-opioid receptor

PM poor metaboliser

UM ultrametaboliser

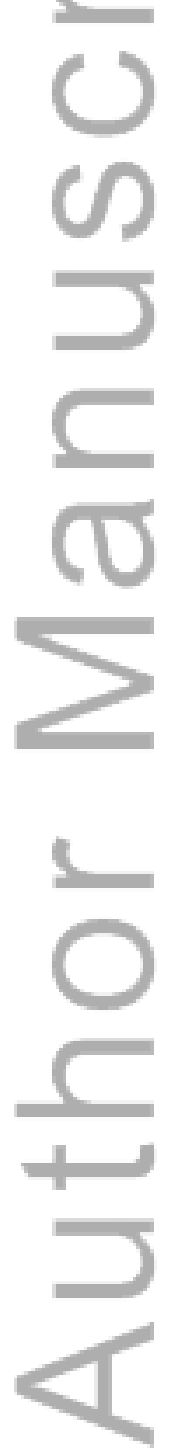

This article is protected by copyright. All rights reserved. 
Figure 1: Picture of metered aerosol device $\left(M \mathrm{MD}^{\circledR}\right)$ used for intranasal medication administration

\section{Choose one of these 2 pictures}

Not sought permission to reproduce pending decision on which to include

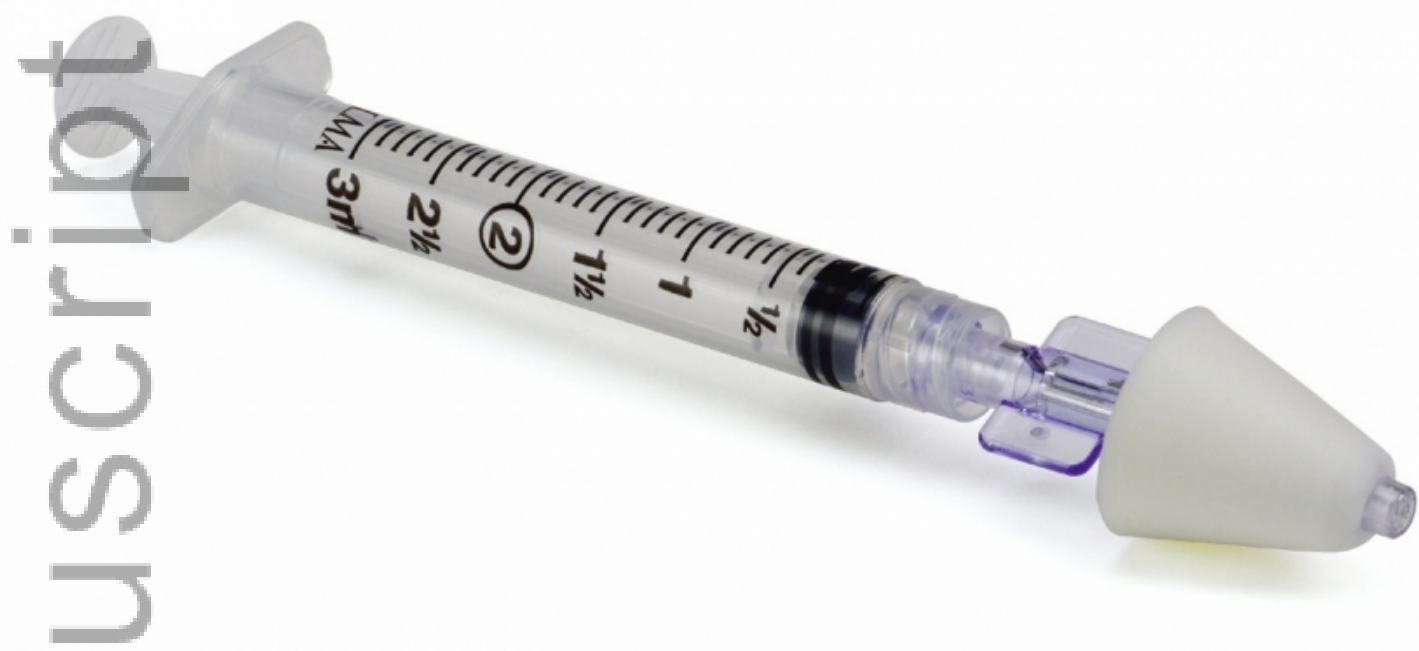

url accessed $9^{\text {th }}$ June 2015 http://www.Imana.com/pwpcontrol.php?pwpID=6359

OR
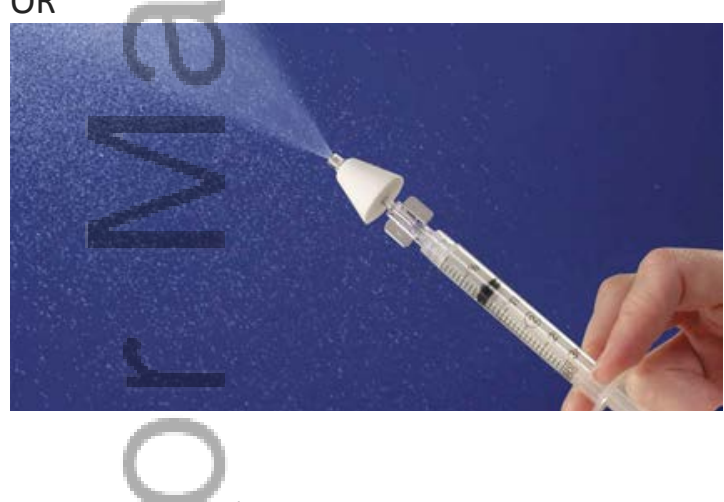

url accessed $9^{\text {th }}$ June 2015: http://prehospitalresearch.eu/?p=3179

From Rapid Reviews: Start picking your nose! Intranasal delivery of medications by Alan Batt. Last modified: 02/10/14

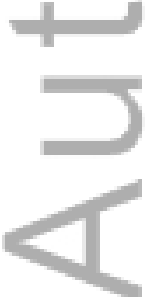

This article is protected by copyright. All rights reserved. 
References:

1. Alexander J, Manno M. Underuse of analgesia in very young pediatric patients with isolated painful injuries. Ann Emerg Med. May 2003;41(5):617-622.

2. Kennedy RM, Luhmann J, Zempsky WT. Clinical implications of unmanaged needle-insertion pain and distress in children. Pediatrics. 2008(5):130.

3. MacLean S, Obispo J, Young KD. The gap between pediatric emergency department procedural pain management treatments available and actual practice. Pediatric emergency care. Feb 2007;23(2):87-93.

4. Hoyle JD, Jr., Rogers AJ, Reischman DE, et al. Pain intervention for infant lumbar puncture in the emergency department: physician practice and beliefs. Academic emergency medicine : official journal of the Society for Academic Emergency Medicine. Feb 2011;18(2):140-144.

5. Ali S, Chambers AL, Johnson DW, et al. Paediatric pain management practice and policies across Alberta emergency departments. Paediatrics \& child health. Apr 2014;19(4):190-194.

6. Paediatric Subsection 9. In: Halliwell RMT, Palmer GM, Trinca JJ, Scott DA, Schug SA, eds. Acute Pain Management: Scientific Evidence 4th Edition. Melbourne: ANZCA \& FPM; 2015.

7. Fein JA, Zempsky WT, Cravero JP. Relief of pain and anxiety in pediatric patients in emergency medical systems. Pediatrics. Nov 2012;130(5):e1391-1405.

8. Wong I, St John-Green C, Walker SM. Opioid-sparing effects of perioperative paracetamol and nonsteroidal anti-inflammatory drugs (NSAIDs) in children. Paediatric anaesthesia. Jun 2013;23(6):475-495.

9. Graham GG, Davies MJ, Day RO, Mohamudally A, Scott KF. The modern pharmacology of paracetamol: therapeutic actions, mechanism of action, metabolism, toxicity and recent pharmacological findings. Inflammopharmacology. Jun 2013;21(3):201-232.

10. Anderson BJ. Chapter 43. The non-steroidal anti-inflammatory drugs and acetaminophen. In: McGrath PJ, Stevens BJ, Walker SE, Zempsky WT, eds. Oxford Textbook of Paediatric Pain. Oxford: Oxford University Press; 2014.

11. Capici F, Ingelmo PM, Davidson A, et al. Randomized controlled trial of duration of analgesia following intravenous or rectal acetaminophen after adenotonsillectomy in children. $\mathrm{Br} J$ Anaesth. Feb 2008;100(2):251-255.

12. Southey ER, Soares-Weiser K, Kleijnen J. Systematic review and meta-analysis of the clinical safety and tolerability of ibuprofen compared with paracetamol in paediatric pain and fever. Current medical research and opinion. Sep 2009;25(9):2207-2222.

13. Lavonas EJ, Reynolds KM, Dart RC. Therapeutic acetaminophen is not associated with liver injury in children: a systematic review. Pediatrics. Dec 2010;126(6):e1430-1444.

14. Misurac JM, Knoderer CA, Leiser JD, Nailescu C, Wilson AC, Andreoli SP. Nonsteroidal antiinflammatory drugs are an important cause of acute kidney injury in children. The Journal of pediatrics. Jun 2013;162(6):1153-1159, 1159.e1151.

15. Musu M, Finco G, Antonucci R, et al. Acute nephrotoxicity of NSAID from the foetus to the adult. European review for medical and pharmacological sciences. Dec 2011;15(12):14611472.

16. Dodwell ER, Latorre JG, Parisini E, et al. NSAID exposure and risk of nonunion: a metaanalysis of case-control and cohort studies. Calcified tissue international. Sep 2010;87(3):193-202. 
17. Kurmis AP, Kurmis TP, O'Brien JX, Dalen T. The effect of nonsteroidal anti-inflammatory drug administration on acute phase fracture-healing: a review. The Journal of bone and joint surgery. American volume. May 2 2012;94(9):815-823.

18. Maund E, McDaid C, Rice S, Wright K, Jenkins B, Woolacott N. Paracetamol and selective and non-selective non-steroidal anti-inflammatory drugs for the reduction in morphine-related side-effects after major surgery: a systematic review. Br J Anaesth. Mar 2011;106(3):292297.

19. Lewis SR, Nicholson A, Cardwell ME, Siviter G, Smith AF. Nonsteroidal anti-inflammatory drugs and perioperative bleeding in paediatric tonsillectomy. The Cochrane database of systematic reviews. 2013;7:CD003591.

20. Murto K, Lamontagne C, McFaul C, et al. Celecoxib pharmacogenetics and pediatric - adenotonsillectomy: a double-blinded randomized controlled study. Canadian journal of anaesthesia = Journal canadien d'anesthesie. Apr 72015.

21. Rattray B, Nugent DJ, Young G. Celecoxib in the treatment of haemophilic synovitis, target joints, and pain in adults and children with haemophilia. Haemophilia : the official journal of the World Federation of Hemophilia. Sep 2006;12(5):514-517.

22. Forrester MB. Cases of pediatric ingestion of celecoxib reported to Texas poison control centers in 2000-2007. Human \& experimental toxicology. Apr 2009;28(4):191-194.

23. Madadi P, Koren G, Cairns J, et al. Safety of codeine during breastfeeding: fatal morphine poisoning in the breastfed neonate of a mother prescribed codeine. Can Fam Physician. Jan 2007;53(1):33-35.

24. Kelly LE, Rieder M, van den Anker J, et al. More codeine fatalities after tonsillectomy in North American children. Pediatrics. 2012;129(5):e1343-1347.

25. Friedrichsdorf SJ, Nugent AP, Strobl AQ. Codeine-associated pediatric deaths despite using recommended dosing guidelines: three case reports. Journal of opioid management. MarApr 2013;9(2):151-155.

26. Tremlett MR. Wither codeine? Paediatric anaesthesia. Aug 2013;23(8):677-683.

27. WHO. WHO Guidelines on the Pharmacological Treatment of Persisting Pain in Children with Medical Illnesses. Geneva: World Health Organisation; 2012.

28. Howard RF, Lloyd-Thomas A, Thomas M, et al. Nurse-controlled analgesia (NCA) following major surgery in 10,000 patients in a children's hospital. Paediatric anaesthesia. Feb 2010;20(2):126-134.

29. Morton NS, Errera A. APA national audit of pediatric opioid infusions. Paediatric anaesthesia. Feb 2010;20(2):119-125.

30. Hansen MS, Dahl JB. Limited evidence for intranasal fentanyl in the emergency department and the prehospital setting--a systematic review. Dan Med J. Jan 2013;60(1):A4563.

31. Borland ML, Clark LJ, Esson A. Comparative review of the clinical use of intranasal fentanyl versus morphine in a paediatric emergency department. Emergency medicine Australasia : EMA. Dec 2008;20(6):515-520.

32. Lotsch J, Walter C, Parnham MJ, Oertel BG, Geisslinger G. Pharmacokinetics of nonintravenous formulations of fentanyl. Clinical pharmacokinetics. Jan 2013;52(1):23-36.

33. Borland M, Milsom S, Esson A. Equivalency of two concentrations of fentanyl administered by the intranasal route for acute analgesia in children in a paediatric emergency department: a randomized controlled trial. Emergency medicine Australasia : EMA. Apr 2011;23(2):202-208. 
34. Crellin D, Ling RX, Babl FE. Does the standard intravenous solution of fentanyl (50 $\mathrm{microg} / \mathrm{mL}$ ) administered intranasally have analgesic efficacy? Emergency Medicine Australasia. 2010;22(1):62-67.

35. Herd DW, Babl FE, Gilhotra Y, Huckson S. Pain management practices in paediatric emergency departments in Australia and New Zealand: a clinical and organizational audit by National Health and Medical Research Council's National Institute of Clinical Studies and Paediatric Research in Emergency Departments International Collaborative. Emergency medicine Australasia : EMA. Jun 2009;21(3):210-221.

36. Yeaman F, Oakley E, Meek R, Graudins A. Sub-dissociative dose intranasal ketamine for limb injury pain in children in the emergency department: a pilot study. Emergency medicine Australasia : EMA. Apr 2013;25(2):161-167.

37. Bendall JC, Simpson PM, Middleton PM. Prehospital analgesia in New South Wales, Australia. Prehospital and disaster medicine. Dec 2011;26(6):422-426.

38. Grindlay J, Babl FE. Review article: Efficacy and safety of methoxyflurane analgesia in the emergency department and prehospital setting. Emergency Medicine Australasia. Feb 2009;21(1):4-11.

39. Stevens B, Yamada J, Lee GY, Ohlsson A. Sucrose for analgesia in newborn infants undergoing painful procedures. Cochrane Database Syst Rev. 2013;1:Cd001069.

40. Bueno M, Yamada J, Harrison D, et al. A systematic review and meta-analyses of nonsucrose sweet solutions for pain relief in neonates. Pain research \& management : the journal of the Canadian Pain Society = journal de la societe canadienne pour le traitement de la douleur. May-Jun 2013;18(3):153-161.

41. Kassab M, Foster JP, Foureur M, Fowler C. Sweet-tasting solutions for needle-related procedural pain in infants one month to one year of age. Cochrane Database Syst Rev. 2012;12:Cd008411.

42. Harrison D, Yamada J, Adams-Webber T, Ohlsson A, Beyene J, Stevens B. Sweet tasting solutions for reduction of needle-related procedural pain in children aged one to 16 years. Cochrane Database Syst Rev. 2011(10):CD008408.

43. Pillai Riddell RR, Racine NM, Turcotte K, et al. Non-pharmacological management of infant and young child procedural pain. Cochrane Database Syst Rev. 2011(10):Cd006275.

44. Taddio A, llersich AL, Ipp M, Kikuta A, Shah V, Team HE. Physical interventions and injection techniques for reducing injection pain during routine childhood immunizations: systematic review of randomized controlled trials and quasi-randomized controlled trials. Clinical therapeutics. 2009;31 Suppl 2:S48-76.

45. Uman LS, Birnie KA, Noel M, et al. Psychological interventions for needle-related procedural pain and distress in children and adolescents. Cochrane Database Syst Rev. 2013;10:CD005179.

46. Wente SJ. Nonpharmacologic pediatric pain management in emergency departments: a systematic review of the literature. Journal of emergency nursing: JEN : official publication of the Emergency Department Nurses Association. Mar 2013;39(2):140-150.

47. Koller D, Goldman RD. Distraction techniques for children undergoing procedures: a critical review of pediatric research. Journal of pediatric nursing. Dec 2012;27(6):652-681. 


\section{University Library}

\section{- M M N E R VA A gateway to Melbourne's research publications}

Minerva Access is the Institutional Repository of The University of Melbourne

Author/s:

Palmer, GM

Title:

Pain management in the acute care setting: Update and debates

Date:

2016-02-01

Citation:

Palmer, G. M. (2016). Pain management in the acute care setting: Update and debates. JOURNAL OF PAEDIATRICS AND CHILD HEALTH, 52 (2), pp.213-220. https:// doi.org/10.1111/jpc.13134.

Persistent Link:

http://hdl.handle.net/11343/290877 